\title{
The Earle W. Webb, Jr. Memorial Library and Civic Center: A Morehead City Landmark Awaits an Uncertain Future
}

\author{
by Susan W. Simpson
}

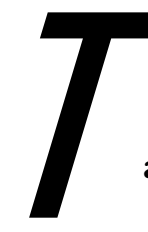

he Earle W. Webb, Jr. Memorial Library and Civic Center, in Morehead City, North Carolina, is a unique institution facing an uncertain future. ${ }^{1}$ Originally established in the 1930s through a private trust, the library is a public institution, but receives no public funds.

Located on the corner of 9th and Evans Streets, Webb Library is a neighborhood library and meeting place. It sits adjacent to the busy waterfront where charter boat and head boat captains take tourists Gulf Stream fishing, "snowbird" boaters traveling the Intracoastal Waterway stop on their way north or south depending upon the season, and multi-national crews peer down from their ships docked at the State Port close by. Recently the nearby town of Beaufort has attracted some of this business away from Morehead City, but both benefit being situated midway between New York and Florida, with access to a reliable, deepwater inlet. The town enjoys what some call "good geography," and Webb Library enjoys some of the best geography in town. City leaders recognize this, and the library is included in the town's promotional literature, which advertises downtown revitalization efforts. These efforts have brought restaurants, art galleries, shops, and a history museum to Webb's neighborhood. M unicipal offices stand nearby and across the street from the library is a multi-story residential retirement center. Even "The Promised Land" is not too far away. This is the name given to that area of town settled around the turn of the twentieth century by families from Core and Shackleford Banks, Outer Bank islands located off Carteret County. Spurred to relocate by a series of devastating hurricanes and failing maritime economies, many "Banker" families floated or sailed their houses from the islands to permanently moor them on lots along M orehead City's Evans and Shepard Streets.

Library users reflect this neighborhood mix of municipal, business, and residential activities, but it is doubtful that many of these users understand the critical situation that their unique neighborhood library faces. ${ }^{2}$

\section{The Beginning}

Earle Wayne Webb, Jr., a student at Durham's Trinity College (now Duke University), collapsed as he stepped off the train in Morehead City. It was December 23, 1932, and he was headed home for Christmas. Before the holiday was over, the young student had died from pneumonia. He was his parents' only son, and they were devastated. The Webbs were among M orehead City's leading families. The father, Earle Webb, Sr., was a self-made man, the sixth of 
eleven children born to Morehead City's tel egraph operator. Earle Webb, Sr. had attended Trinity like his son, but graduated from the University of Michigan in 1902, before completing a law degree at New York University. It was in the big city that Webb met his wife Eva Arnold, and, in 1921, he became an attorney with General Motors. That's where he met and attracted the "favorable attention" of Alfred P. Sloan, Jr., who was an officer in the corporation. As a result, Mr. Webb was eventually placed on the board of directors for General M otors Chemical Corporation, the company, which took the "knock" out of engines by placing lead in gas. Webb was named President of Ethyl Gasoline Corporation in 1925 and remained at the helm until 1947. ${ }^{3}$ This captain of industry never forgot his hometown.

\section{Earle W. Webb, Sr.}

The Webbs returned to Morehead City on frequent visits, and Earle, Sr. eventually built a large vacation and retirement home outside of town on Bogue Sound (now Brandywine Bay). He owned one of Morehead City's four cars and gave a lift to anyone who asked for it. His wife, who bought her new clothes in New York City, al ways made sure to donate her old

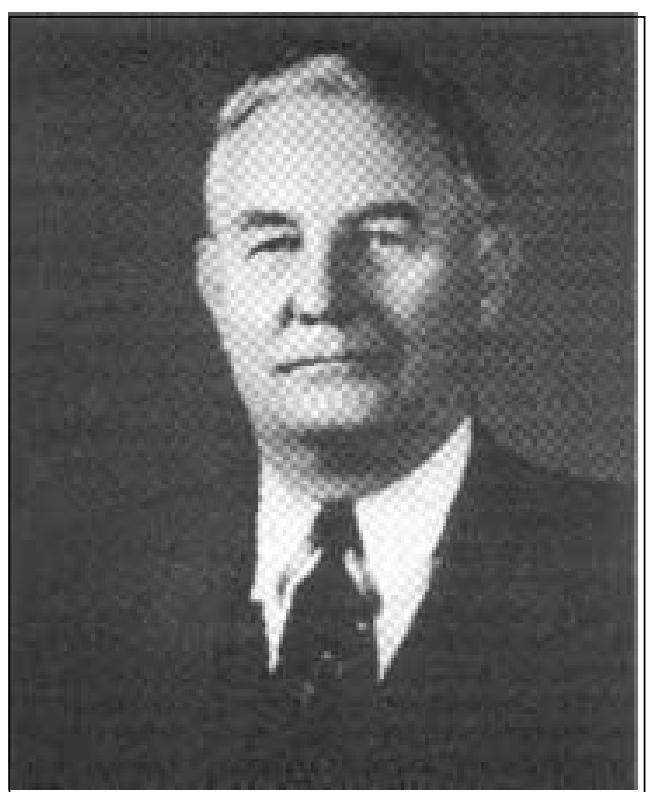

Earle W. Webb, Sr. set up the irrevocable trust to support the building and its operations. things to the needy in Morehead. It was only natural that the Morehead City Woman's Club would turn to the Webbs for help with their public library project.

In 1934, the Morehead City Woman's Club established the Morehead City Library in one second-floor room of the municipal building (now the town's police and fire department). When the collection grew to 1,278 volumes, threatening to spill out in the hall, the ladies understandably asked the town officials for more space. They were denied. ${ }^{4}$ Sitting nearby at the corner of 9th and Evans Street, was a 10,000 square-foot, two-story, red-brick office building that Earle Webb, Sr. had recently constructed. The Great Depression hadn't limited its rental potential. Since it sat close to a new hospital, two doctors maintained offices on the first floor, while the second floor housed different businesses, including at one time a garment company. The ladies of the Woman's Club petitioned Mr. Webb for library space, and he obliged them with use of one upstairs room (now the library's Classics Room). An adjoining telephone closet served as the librarian's office. Like many Woman's-Clubsponsored libraries of those days, the M orehead City Library grew at a rapid pace, and eventually the Woman's Club took over the entire building, "running off" all the businesses in the building, except for the two doctors. Books spread through two downstairs rooms and the children's library and reading room filled the upstairs.

The local Woman's Club maintained a regular correspondence with Earl Webb and ultimately influenced his decision to give up on the building's commercial potential and memorialize his son, the former Trinity student, by dedicating his building to public service, "to promote educational, charitable, and religious causes." In 1937, the Woman's Club honored the Webb Family by dedicating the Earle W. Webb, Jr. Memorial Civic Center and Library. At the same time, Earle Webb, Sr., set up the irrevocable trust to support the building and its operations. It had taken the ladies of Morehead City only three years to move from a small room in a municipal building to an endowed brick library building, and it was the Webb family - in the midst of the Great Depression - that made that leap possible.

The Webb Center became a hub of civic activities as many organizations held their meetings in the various rooms, not the least of which were the allimportant ladies' bridge tournaments. The Morehead City Woman's Club claimed one upstairs room as space for their meetings and designated one 
downstairs the "Gentleman's Room." Eyewitnesses say that when the Gentleman's Room door opened, cigar and pipe smoke streamed out into the hall where a sign read, "Smoking is Allowed \& Dogs Must Be Carried." Not too far away, library volunteer clerks smoked, too, as they checked books in and out. It was a busy and noisy and much-loved place.

\section{Webb Library Today}

A wooden office desk just inside the Evans Street door wel comes users to the Webb Library. On it, sit three oversized rolodexes, filled with borrower information. New users may check out one book; if that is properly returned within the three-week loan period, he or she can check out more. (Fines run ten cents a day.) Parents sign out their children's books, and the venerable card inside the back cover serves as the circulation record. Dark pine wood paneling, antique chandeliers, sofas, reading lamps, easy chairs, and the pervasive aroma of lemon polish furnish the ten rooms that make up the library, each featuring one or two complete wall-length custom bookcases. The downstai rs center hal I way features a large portrait of Earl Webb, Jr.

The first floor houses most of the library's book collection. The Webb Library divided its collection by genre long before mega-bookstores made the practice popular. The Mystery Room, across from the circulation desk, has an impressive selection of new authors and titles, and "general fiction" is in an adjoining room. The Military History room contains a bookcase of titles arranged chronologically from the Spanish American War, ending with the Gulf War, and across the hall is the former home of the Carteret County Historical Association's local history collection. (The Association moved recently into its new "History Place" on Arendell Street, and with it went the Webb's local history and geneal ogy materials.) Books by North Carolina authors rest

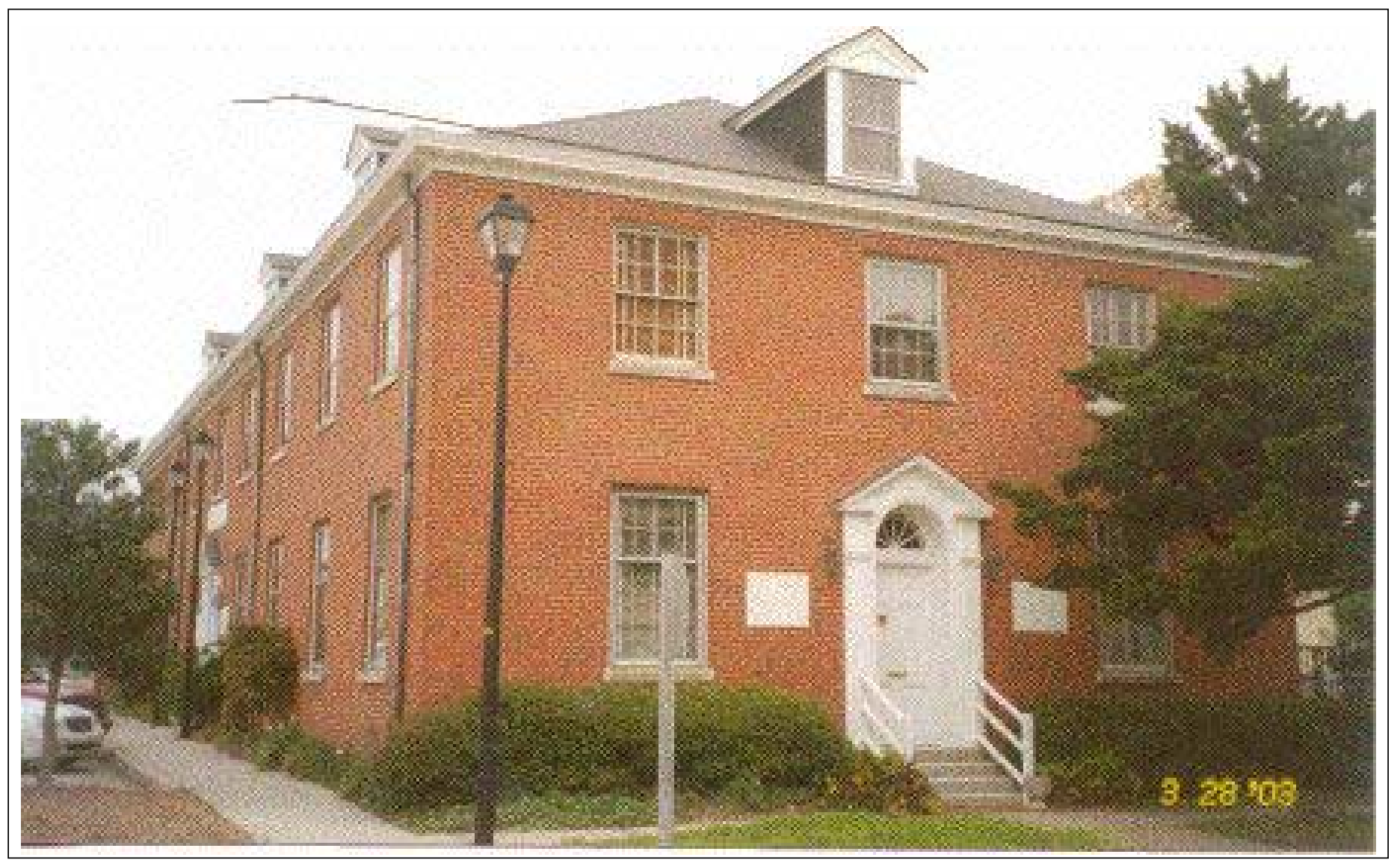

The original 10,000 square-foot building at 812 Evans Street is included in the revitalization efforts of downtown Morehead City. 
in the hallway, and the reference and general nonfiction room follows Dewey Decimal Classification, a guide to which is framed and hangs on the wall. There are "BC" books (Biography Contemporary), and "BH" books (Biography Historical), and "CB" titles (Children's Books). The reference section is small, and in a far corner sits the one computer in the library, an Internet access station for public use. (A local Internet Provider, http://www.starfishnet.com, supplied the computer and the dial-up access. Printing is 25 cents per page.) Travelers use the computer to check their e-mails. Others may check the online catal og of the Carteret County Library in nearby Beaufort (a constituent of the Craven-Pamlico-Carteret Regional Library). There is a lounge (a former kitchen), technical services area, and a couple of offices on the first floor as well.

A carpeted stairway leads up to the second floor where there are four large rooms. The Carteret County Arts Council currently rents one for a studio, and another, the Carol Webb Beyer Meeting Room, is available to the public for meetings, special events, or private parties. Also upstairs is the Eva Arnold Webb Children's Reading Room and Library. Story times and the summer reading programs are conducted in this spacious room full of books, toys, and decorations. The children's books are classified with color codes, and easy books are kept on the bottom shelf. As children grow, the books for their age group climb the bookcase. The fourth room contains the Franklin Moffitt Classics Reading Room, a spot just a bit musty with the smell of old books and leather bindings.

When Earle Webb, Sr. passed away in 1965, books from his personal library were donated to Webb Library with some mistakenly going to his alma

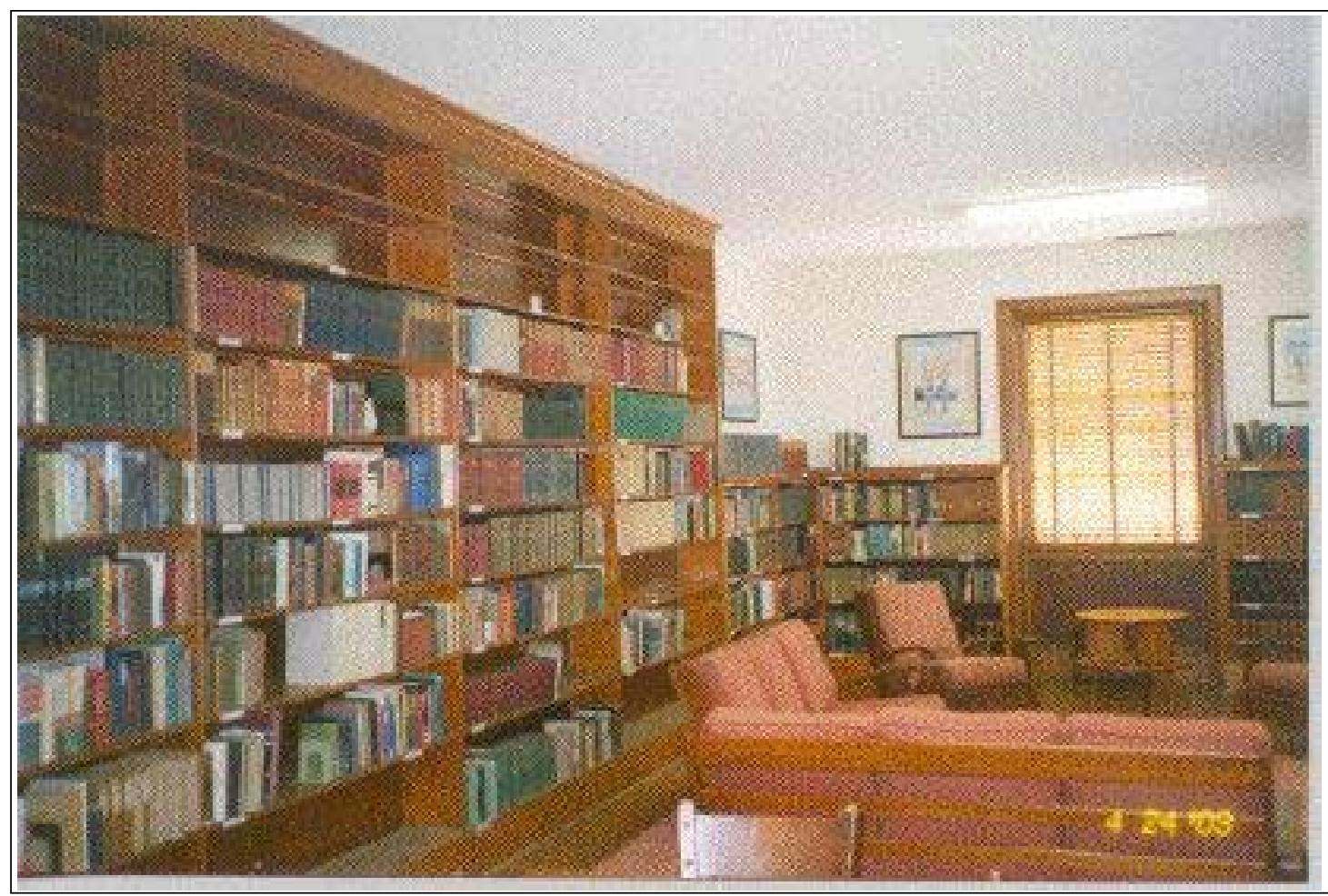

In the Classics Reading Room, the books are arranged generally in chronological order of date of publication. mater, Duke University. It took some years but eventually Webb's entire collection of 1,700 volumes were deposited with the Webb Library. The librarian at the time, Marion Chandler, thought it would be a good idea to keep Mr. Webb's books together. A recently retired Stanford professor of literature offered to help, provided he could arrange the books as he wanted. The result is the Classics Reading Room where the books are arranged generally in chronological order of date of publication. Reshelving is aided by a special code penciled onto the books, indicating the home bookcase, unit, and shelf.

Presiding over this collection since 1996 is Gloria Fleming, a retired Special Education teacher and former Peace Corps volunteer. Hel ping her are two part-time employees who work eight hours a week and eight volunteers who assist with day-to-day operations. Fleming reports to a Board of Trustees composed of Webb family members. The three remaining trustees live in Florida 
and rarely visit Morehead City, giving the director a great deal of flexibility.

Fleming keeps no operational statistics because such information "has never been requested by the trustees." She estimates that the library has

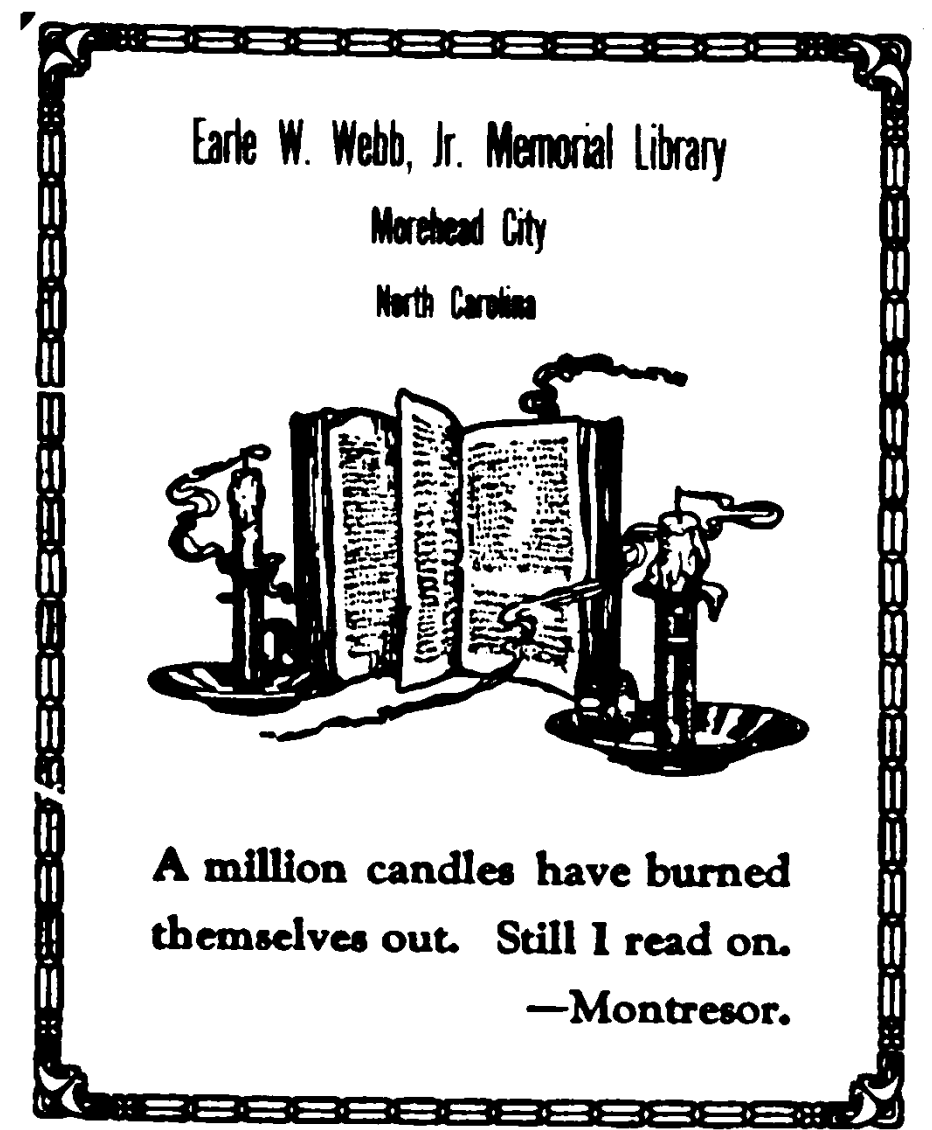

Classification information is hand printed on spine labels that were adapted from the library's original bookplate. about four hundred registered borrowers and that its circulation has fallen in recent years to about twentyfive books per day. No one knows how many items are held by this books-only library, but there are considerably fewer than the accession record's 40,000 . No one has kept track of the number of lost or withdrawn items over the years.

According to Lorna Bertino, retired librarian (M.L.S., Long Island University) who worked at Webb Library part-time for six months, when Fleming started there was no classification system and no organization to the books, although a shelflist existed. (A few years ago volunteers from Carteret Community College entered shelflist information into a software program, the list was printed and copies were made available to the county library in Beaufort and the community college library. This database has not been updated in about a year, although shelflist cards are kept for all new books received.) With one volunteer and reference materials from the county public library, the two women set up the different genre rooms, and catal oged the entire collection. The women also attached the attractive spine labels that were adapted from the library's original bookplate. (Classification information is hand printed on the label.) "It's nice to see the results of what we did," Bertino says.

\section{Budget and Physical Maintenance}

Webb Library was established through a trust, and its portfolio generates revenue, which supports the li-

brary. In the eyes of the U.S. Internal Revenue Service, Webb Library is "a private trust operating as a charitable public foundation." It holds tax-exempt status, but also generates income. Up until the late 1970s the librarian also handled the stock transactions as instructed by absent advisors. The librarian would take funds down to the local broker with instructions to buy or sell specific stock. This practice had ended by the time Fleming's predecessor, Marion Chandler, became librarian in 1987.

Fleming is quick to say there is no budget, but when pressed it becomes clear that she does not have a formal administrative budget (and thus no planning tool), but she has an excellent grasp on how much it costs to operate the Webb Library. In her monthly report to the Trustees, she itemizes the library's expenses and revenues. The broker sends a monthly check of about $\$ 3,700$ (although Fleming comments that "one never really knows how much"), which she uses to pay the bills, including payroll. The director receives a salary of about $\$ 14,400$ (remember, she is full-time), and the two part-time employees receive a stipend of $\$ 1,800$. When large expenses are anticipated, like annual insurance premiums, Fleming writes the trustees to request additional money. Books are purchased through Ingram and from local bookstores, which give Webb Library good discounts. At one time, Fleming spent about $\$ 400$ a month on books, but recently that has dropped to $\$ 200$. The library does, however, receive many welcome donations and a few fines. Other funds come from the Carteret County Arts Council, which rents space and charges groups using the library meeting room and kitchen. (It costs $\$ 25$ 
to hold a meeting after regular library office hours; no charge if the library is open. About once a month a private reception or shower is held, and these are charged \$100.) Webb Library also has an artist in residence who pays $\$ 175$ a month for a small studio space. (At one time, Fleming says, the library had three artists in residence.)

Ms. Fleming also has a firm appreciation for all the labor volunteered (especially by her husband) to keep the building going. The Webb Library facility is 10,000 square feet and was built in the 1930s. (The structure was built to accommodate a third floor, which is now taken up largely with ductwork.) It has a basement with moisture problems, frequently requiring new sump pumps; many of the walls are stucco, which require constant care even though the building now has central air-conditioning and heating. The plumbing and electrical fixtures are old. Volunteer labor cleans, maintains the gardens, and keeps the entire operation neat and spotless. Groups that meet in the building know that Fleming expects the room to be as they found it. "This building is like a big house and I'm the mother!" she says.

\section{Challenges}

The Webb Library continues to be funded through investment revenue of the original trust established by Earle Webb, Sr. and administered by a Board of Trustees composed of three of his descendants, none of whom lives in the area. As interest rates have plummeted and the Stock Market has declined, so has investment income. Sadly, even the trust's principal has dwindled, leaving little to invest. As Fleming says, "It is just hard to swallow that the bottomless pit of money is drying up."

The Trustees have contacted Fleming about the dire situation, and, they have scheduled a visit in June 2003 to discuss alternatives and options. She was told she needed to raise $\$ 50,000$ and was encouraged to pursue local fundraising efforts, even seek corporate sponsorship from sports-fishing tournament interests, but she balks at this. She maintains that fundraising at that

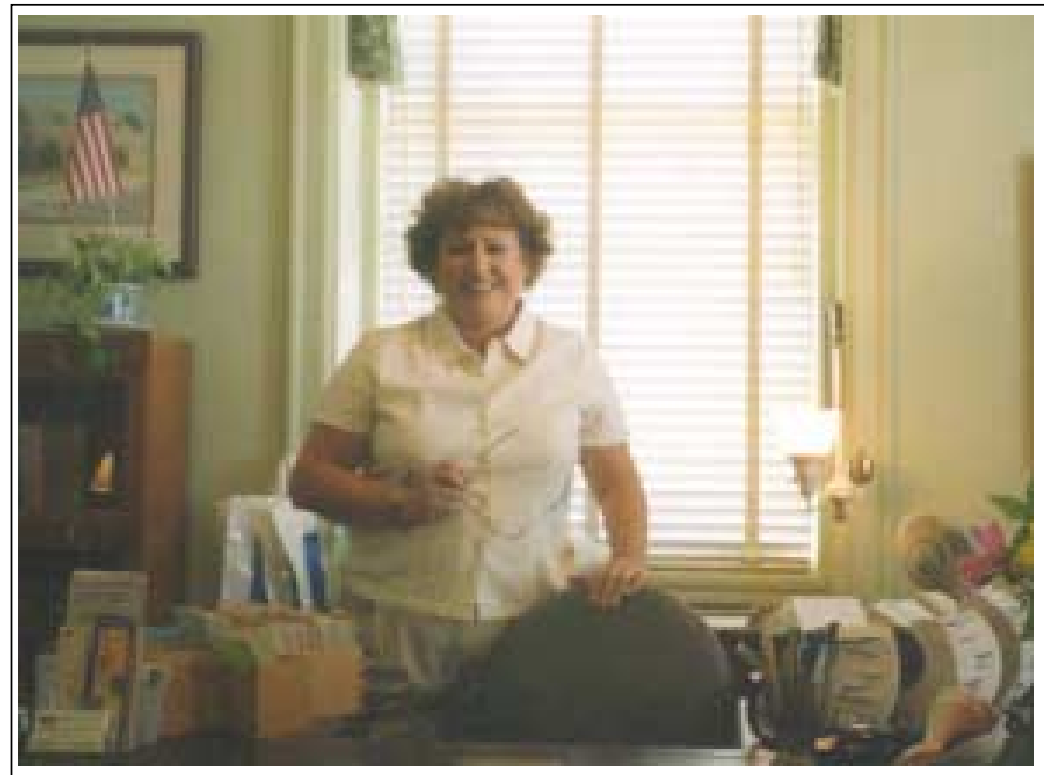

Gloria Fleming, a retired Special Education teacher and former Peace Corps volunteer, presides over the collection. level is not her job, nor her expertise. One option before the trustees is to sell the building, which would essentially be the end of Webb Library.

Fleming has explored various ideas for keeping Webb Library afloat. She approached the town of Morehead City for an appropriation, but was turned down. Officials said the town al ready has a public library in the community college library, which is catering more and more to the general public.

In an option that interests the trustees, the Carteret County Arts Council proposes to fund the library's budget (an unknown amount of money) in exchange for rent. Fleming was shocked when she overheard members of the Arts Council discussing among themselves plans to move the Children's Room downstairs and dispose of ("give away or sell") the entire classics collection. In a grim moment she admits to preferring that the library be dissolved rather than suffering a slow death under such

an administration.

Incorporating Webb Library into the regional public library system faces many economical, technical, and political complications. Presently a new branch library is under construction in the western part of the county and soon to open, but only because a group of individuals formed a Friends 
group and raised $\$ 250,000$ to make it happen. Frankly, Webb Library lacks the cohesive energizing public support (like a Friends of the Library organization) that could galvanize such action. A few years ago Fleming put on a gala reception to honor the trustees on one of their rare visits. Invitations were sent out, food was catered, wine donated, and musicians arranged. Although the weather was poor, al most 250 people attended. A sign-up sheet was available that night for anyone interested in forming a Friends of Webb Library organization. About forty persons attended the first meeting, a number that dropped to five at the second meeting. Fleming blames the magnitude of the fundraising needed for the drop in interest.

\section{Dreaming the Future?}

What if money was not a problem? Fleming is quick to answer. She would like longer operating hours, even Sunday hours; more computers with fast Internet access for the public (she is neutral on automating library operations); and third on her list would be attention to the integrity of the building itself, which needs new windows, new plumbing, and foundation work. Her colleague, Bertino, identifies similar issues. There is a need for a catalog to the collection. Without it, access to the book collection is limited, and, she believes, there needs to be less dependence on volunteers "who are hard to depend on."

But, when she was asked about the strengths of the Webb Library, Bertino did not hesitate to answer. She quickly identified the library's service to and close ties with the citizens of Morehead City and Carteret County for almost seventy years. Even today, the Webb Library and Civic Center remains a busy place. Children walk to the library from a nearby parochial school, homeschoolers use its resources, the Morehead City Woman's Club, Book Club, and Garden Club continue to meet upstairs, as does the local chapter of the Daughters of the American Revolution. Municipal committees and civic organizations also make use of the facilities so conveniently located to the municipal offices. And, of course, there are those who still visit, claim a chair to read, or take a book home.

The Earl Webb, Jr. Library and Civic Center is a community facility, a part of Morehead City's history, looking for a secure place in its future.

Everyone agrees that its future is uncertain.

\section{References}

1 I am grateful to Gloria Fleming, librarian and director of Webb Memorial Library for her time, patience, and confidences. A great deal of the information in this paper came from her. Also, I thank Dr. Veronica S. Pantelidis and Thomas Kevin B. Cherry of the Department of Librarianship, Educational Technology, and Distance Instruction at East Carolina University for their instruction and encouragement.

2 "A Legacy of Books" Carteret County News-Times, June 28, 1998.

3 Robert, Joseph C. Ethyl: A History of the Corporation and the People Who Made It. University Press of Virginia, Charlottesville. 1983. pp. 128-74.

4 Morehead City Woman's Club. A Pictorial Review of Morehead City History 1714-1981. Complied and published by the Club in 1982. pp. 174-76.

\section{Visitor Information}

Downtown Morehead City is undergoing major revitalization efforts, and Webb Library is included on an advertising Web page: www.downtownmoreheadcity.com/Attractions/webblibrary.htm. 